\title{
Effects of cattle and poultry manures on organic matter content and adsorption complex of a sandy soil under cassava cultivation (Manihot esculenta, Crantz)
}

\author{
S. Bakayoko ${ }^{1,2 *}$, D. Soro ${ }^{1,2}$, C. Nindjin', D. Dao', A. Tschannen', O. Girardin ${ }^{3}$ and A. Assa ${ }^{4}$ \\ ${ }^{1}$ Swiss Centre for Scientific Research (Centre Suisse de Recherches Scientifiques) in Côte d'Ivoire, 01 BP 1303 Abidjan \\ 01, Côte d'Ivoire. \\ ${ }^{2}$ University of Abobo-Adjamé (University d'Abobo-Adjamé), UFR SN, Laboratory of biology and crop production, 02 BP \\ 801 Abidjan 02, Côte d'Ivoire. \\ ${ }^{3}$ Rural Foundation of Jura, Courtemelon Loveresse (Fondation Rurale Interjurassienne), Post-office box: 65/2852, \\ Courtetelle, Swiss. \\ ${ }^{4}$ University of Cocody (University de Cocody), UFR STRM, Laboratory of Soil Science and Geology, 22 BP 582 Abidjan
} 22, Côte d'Ivoire.

Accepted 14 July, 2009

This study examined the A and B horizons of deep, developed and moderately unsaturated sandy ferrallitic soils amended with cattle and poultry manures under cassava (Manihot esculenta Crantz) cultivation. Therefore, a plot experiment was carried out by using a randomized complete blocks design in 4 replications and fields treatments which included unfertilized (control) and one dose (10 t/ha) of both manures. The study of the different fractions of animal manures showed that the poultry had the greatest content of $\mathbf{C}$ (organic carbon), $\mathbf{N}$ (nitrogen), P (phosphorus), $\mathrm{K}$ (potassium), Ca (calcium) and $\mathrm{C}: \mathrm{N}$ ratio $(\mathrm{p}<0.01)$. However, the value of $\mathrm{Mg}$ (magnesium) in the studied manures was not significantly different $(p<0.01)$. The manure treatment significantly increased the soil organic matter contents from 0.46 to 2.8 and $1.1 \%$ respectively with poultry and cattle manures $(p<0.01)$. Organic fertilizer significantly increased the cation exchange capacity from 1.7 to 12.75 and $3.8 \mathrm{me:100} \mathrm{g}$ and the bases saturation content from 47 to 80 and to $76 \%$ respectively with the poultry and cattle manures $(p<0.01)$. The organic fertilizer showed significant effect on earthworms populations Hyperiodrilus africanus (Oligochaeta, Eudrilidae) in the soil, with 128 and $85 \%$ respectively about the poultry and cattle manures compared to the control $(p<0.01)$.

Key words: Cattle manure, poultry manure, cassava, organic matter, cation exchange capacity, bases saturation content.

\section{INTRODUCTION}

Cassava is grown in every agroecological zone of the Côte d'Ivoire and it is the major food crop after yam. Cassava is often the last crop grown before the land is allow-

${ }^{*}$ Corresponding author. E-mail: sidiky_bakayoko@yahoo.fr, sidiky.bakayoko@csrs.ci. Tel.: +225 $234 \overline{7} 27$ 90/07 414183. Fax: +22523451211. ed to revert to bush fallow in traditional cropping systems (Ofori, 1973). Côte d'Ivoire is a country with high density of population (48 inh. $\left./ \mathrm{km}^{2}\right)$ and a high population increase rate of $3.8 \%$ /year (Institute National de la Statistique, 1998).This situation causes a strong pressure on the cultivable lands, and considerably reduces the fallow duration. This led to an impoverishment of the soil because of their consecutive overexploitation which is combined to 
bush fires actions (Carsky, 2003). Swarup et al (2000) reported the loss of soil organic carbon, particularly $\mathrm{C}$ and $\mathrm{N}$, under intensive cropping and continuous cultivation. The decline in soil productivity as a result of continuous cultivation in sub-Saharan Africa has been identified as a major cause of food insecurity and poverty and crop yields continue to decline on smallholder farmers fields and there is a huge gap between potential crop yields and actual crop yields (Yeboah et al., 2009). The degradation induces a significant decrease of the soil organic matter content which modifies the nitrogen cycle (Ouattara et al., 2006). Moreover, in Côte d'Ivoire, the low levels of organic matter and total nitrogen $(\mathrm{N})$ were the major soil constraints identified (Asadu et al., 1998). The soil constraints that reduce the yields of cassava such as soil alkalinity and salinity, exchangeable aluminium (Al), high pH above 8.0 and exchangeable sodium $(\mathrm{Na})$ percentage of above $2.5 \%$ have been outlined by Cock and Howeler (1978).

In the other side, the farms generate an enormous amount of manure. The disposal of these wastes is one of the main environmental problems related to intensive livestock production. The use of manures as organic fertilizer can benefit agriculture and can be, potentially, an inexpensive way for society to protect the environment and to conserve natural resources.

Research studies about the cattle manure, aiming the soils fertility regeneration, were implemented elsewhere (Nyamangara et al., 2001; Arriaga and Lowely, 2003; Hao et al., 2004). The information on effect of poultry and cattle manures on soil quality is limited in Côte d'Ivoire. Indeed, the quantification of the organic matter content, the sum of the exchangeable bases cations, the cation exchange capacity and the bases saturation content are of prime importance in identifying sustainable systems for manures dynamics in the soil.

In this study, research programs were carried out in 2002 on plots which were continuously cultivated, since 1992. After the physical and chemical characterizations of these soils, a fertilization trial with cattle and poultry manures under cassava crop were carried out. At the end of the cropping season, each treatment soil was sampled and analyzed. Mineralisation of humus takes place at a slow rate which varies mainly in relation to temperature and soil wetness, factors over which no management controls can be exerted (Moares et al., 2001), Harris (2002) pointed the importance of manure as a nutrient source in the nutrient balances of two farming systems.

The objectives of this study were: i) The characterisa-tion of the different organic matter in animal manures. ii) The determination of the manures effects on organic matter content and adsorption complex of the soil under cassava cultivation.

\section{MATERIALS AND METHODS}

\section{Site description}

The study was carried out on the experimental field of the Swiss Centre for Scientific Research in Bringakro (altitude $150 \mathrm{~m}$, $06^{\circ} 40^{\prime} \mathrm{N}, 05^{\circ} 09^{\prime} \mathrm{W}$ ) located at $180 \mathrm{~km}$ from Abidjan (Côte. d'Ivoire) northward. The climate is a transition of the equatorial climate characterized by the alternation of long rainy season (from March to July) with an average rainfall of $850 \mathrm{~mm}$, a short dry season (from July to August), a short rainy season (from September to October) providing approximately $185 \mathrm{~mm}$ and a long dry season (from November to February). The Harmattan, dry wind blows from December to February during the long dry season. The annual average temperature was $26^{\circ} \mathrm{C}$ with average air moisture of $77 \%$ and a monthly total solar radiation of $394 \mathrm{MJ} / \mathrm{m}^{2}$ from 2002 to 2006. The experiment began in 1992 with a yam crop on land cropped to yam during 10 years. After a short fallow period of 2 months the soil was primarily covered by Imperata cylindrica (Poaceae), Chromolaena odorata (Asteraceae).

The morpho-pedological characterization indicated the presence of well draining soils and wet in-depth. In each horizon, the colour was homogeneous (dark in the top horizon and red in the depth horizon). Twenty seven (27) pedological pits of $1 \mathrm{~m}$ depth were excavated in the field to examine the soil profile and ensure that the same soil type was present. Soil samples were taken according to horizon levels (top horizon $(0-22 \mathrm{~cm})$ and subjacent horizon (22 $55 \mathrm{~cm})$ ) and analyzed at the laboratory. These taking away were made at cuttings planting time in June.

The Table 1 shows initial soil physical and chemical (carbon, nitrogen and organic matter content) properties. Particles size distribution was measured after oxidation of the organic matter with hydrogen peroxide $\left(\mathrm{H}_{2} \mathrm{O}_{2}\right)$ of a soil sample sieved through $2 \mathrm{~mm}$ mesh, followed by particles dispersion with a sodium hexametaphosphate solution $\left(\mathrm{NaPO}_{3}\right)_{6}(\mathrm{Van}, 1993)$. Sands were dominating in the topsoil (approximately $80 \%$ ). The clay content increased gradually with soil depth (5.2 to $8.6 \%$ ) but remained lower than silts which had approximately $13 \%$.

The initial soil chemical properties (cations exchange capacity, potassium, calcium, magnesium and sodium contents, sum of exchangeable bases cations and bases saturation rate) for the site under study are presented in Table 2. Soil organic carbon was determined using the Walkley and Black method (1934). The total nitrogen was measured by dried combustion and by Kjeldahl method (Moral et al., 2005). The exchangeable base cations $\left(\mathrm{Na}^{+}, \mathrm{K}^{+}\right.$, $\left.\mathrm{Ca}^{2+}, \mathrm{Mg}^{2+}\right)$ were extracted with the ammonium acetate $\left(\mathrm{NH}_{4} \mathrm{OaC}\right)$ and proportioned by spectroscopy of atomic absorption for $\mathrm{Ca}$ et $\mathrm{Mg}$ and by spectroscopy from emission to flame for $\mathrm{Na}$ et $\mathrm{K}$ (Houba, 1995). The cation $\mathrm{Ag}^{+}$contents were determined by comparison with those obtained with a "white" witness sample. Exchangeable aluminium $\left(\mathrm{Al}^{3+}\right)$ and extractable hydrogen $\left(\mathrm{H}^{+}\right)$by the cobaltihexamine were measured by AFNOR methods (AFNOR, 1996).

\section{METHODS}

\section{Chemical characteristics of Cattle and poultry manures}

The analyses of the chemical characteristics of poultry and cattle manures used are summarised in the Table 3 . The dry manure samples of cattle were obtained in 7 bovine parks (average age: 2 years) of the village of Bringakro. Concerning the poultry manure, it 
Table 1. Initial soil physical and chemical (carbon, nitrogen and organic matter content) properties at $0-22$ and $22-55 \mathrm{~cm}$ soil layers in the ferrallitic soil of the Toumodi area, Côte d'Ivoire. Data are means \pm standard error.

\begin{tabular}{|c|c|c|c|c|c|c|c|c|}
\hline Horizon & $\begin{array}{r}\text { Clay } \\
(\%)\end{array}$ & $\begin{array}{c}\text { Fine silt } \\
(\%)\end{array}$ & $\begin{array}{c}\text { Coarse silt } \\
(\%)\end{array}$ & $\begin{array}{c}\text { Fine sand } \\
(\%)\end{array}$ & $\begin{array}{c}\text { Coarse sand } \\
(\%)\end{array}$ & $\begin{array}{c}\text { C } \\
(\%)\end{array}$ & $\begin{array}{c}N \\
(\%)\end{array}$ & C:N \\
\hline \multicolumn{9}{|c|}{ Top } \\
\hline $0-22$ & $5.4 \pm 0.6$ & $5.3 \pm 0.4$ & $7 \pm 1.2$ & $18 \pm 2.3$ & $64.3 \pm 6.1$ & $0.53 \pm 0.08$ & $0.045 \pm 0.002$ & $12 \pm 0.9$ \\
\hline $22-55$ & $8.8 \pm 0.7$ & $3.9 \pm 0.1$ & $7.4 \pm 0.8$ & $16.2 \pm 1.9$ & $62.3 \pm 4.9$ & $0.34 \pm 0.04$ & $0.045 \pm 0.007$ & $8 \pm 0.7$ \\
\hline \multicolumn{9}{|c|}{ Middle } \\
\hline $0-22$ & $5.2 \pm 0.9$ & $5.6 \pm 0.3$ & $9.4 \pm 1.4$ & $20 \pm 2.5$ & $59.8 \pm 5.3$ & $0.52 \pm 0.07$ & $0.045 \pm 0.006$ & $12 \pm 0.9$ \\
\hline $22-55$ & $8.6 \pm 1.1$ & $4.1 \pm 0.2$ & $7.8 \pm 1.1$ & $20.2 \pm 2.6$ & $59.3 \pm 5.1$ & $0.34 \pm 0.05$ & $0.045 \pm 0.008$ & $8 \pm 0.9$ \\
\hline \multicolumn{9}{|c|}{ Base } \\
\hline $0-22$ & $5 \pm 0.3$ & $5.9 \pm 0.2$ & $12.7 \pm 1.3$ & $20.8 \pm 1.9$ & $55.6 \pm 4.8$ & $0.52 \pm 0.09$ & $0.045 \pm 0.004$ & $12 \pm 0.2$ \\
\hline $22-55$ & $8.4 \pm 0.7$ & $4.3 \pm 0.3$ & $8.5 \pm 0.9$ & $24.8 \pm 2.9$ & $54 \pm 3.9$ & $0.34 \pm 0.07$ & $0.045 \pm 0.004$ & $8 \pm 0.3$ \\
\hline \multicolumn{9}{|c|}{ Mean } \\
\hline $0-22$ & $5.2 \pm 0.7$ & $5.6 \pm 0.3$ & $9.7 \pm 0.6$ & $19.6 \pm 2.3$ & $59.9 \pm 5.5$ & $0.52 \pm 0.08$ & $0.045 \pm 0.004$ & $12 \pm 0.6$ \\
\hline $22-55$ & $8.6 \pm 0.9$ & $4.1 \pm 0.2$ & $7.9 \pm 0.9$ & $20.4 \pm 2.5$ & $58.5 \pm 4.8$ & $0.34 \pm 0.06$ & $0.045 \pm 0.006$ & $8 \pm 0.5$ \\
\hline
\end{tabular}

Table 2. Initial soil chemical properties (cations exchange capacity, potassium, calcium, magnesium and sodium contents, exchangeable bases sum and bases saturation rate) at $0-22$ and $22-55 \mathrm{~cm}$ soil layers in the ferrallitic soil of the Toumodi area, Côte d'Ivoire. Data are means \pm standard error.

\begin{tabular}{|c|c|c|c|c|c|c|c|}
\hline Horizon & $\begin{array}{c}\text { CEC } \\
(\mathrm{me}: 100 \mathrm{~g})\end{array}$ & $\begin{array}{c}\mathrm{Ca} \\
(\mathrm{me}: 100 \mathrm{~g})\end{array}$ & $\begin{array}{c}\mathrm{Mg} \\
(\mathrm{me}: 100 \mathrm{~g})\end{array}$ & $\begin{array}{c}\mathrm{K} \\
(\mathrm{me}: 100 \mathrm{~g})\end{array}$ & $\begin{array}{c}\mathrm{Na} \\
(\mathrm{me}: 100 \mathrm{~g})\end{array}$ & $\begin{array}{c}\mathrm{S} \\
(\mathrm{me}: 100 \mathrm{~g})\end{array}$ & $\begin{array}{c}\mathrm{V} \\
(\mathrm{me}: 100 \mathrm{~g})\end{array}$ \\
\hline \multicolumn{8}{|c|}{ Top } \\
\hline $0-22$ & $2.4 \pm 0.2$ & $0.733 \pm 0.03$ & $0.066 \pm 0.007$ & $0.058 \pm 0.001$ & $0.023 \pm 0.004$ & $0.88 \pm 0.09$ & $37 \pm 2.5$ \\
\hline $22-55$ & $2.8 \pm 0.5$ & $0.604 \pm 0.08$ & $0.064 \pm 0.007$ & $0.048 \pm 0.003$ & $0.033 \pm 0.004$ & $0.749 \pm 0.09$ & $27 \pm 1.9$ \\
\hline \multicolumn{8}{|c|}{$\begin{array}{c}\text { Middle } \\
\end{array}$} \\
\hline $0-22$ & $2.4 \pm 0.3$ & $0.733 \pm 0.06$ & $0.067 \pm 0.003$ & $0.058 \pm 0.007$ & $0.024 \pm 0.002$ & $0.882 \pm 0.01$ & $37 \pm 2.3$ \\
\hline $22-55$ & $2.8 \pm 0.5$ & $0.602 \pm 0.01$ & $0.064 \pm 0.009$ & $0.048 \pm 0.004$ & $0.033 \pm 0.003$ & $0.747 \pm 0.07$ & $27 \pm 0.9$ \\
\hline \multicolumn{8}{|c|}{ Base } \\
\hline $0-22$ & $2.4 \pm 0.9$ & $0.733 \pm 0.05$ & $0.068 \pm 0.004$ & $0.058 \pm 0.005$ & $0.022 \pm 0.003$ & $0.881 \pm 0.03$ & $37 \pm 0.7$ \\
\hline $22-55$ & $2.8 \pm 0.7$ & $0.6 \pm 0.04$ & $0.064 \pm 0.008$ & $0.048 \pm 0.006$ & $0.033 \pm 0.007$ & $0.745 \pm 0.06$ & $27 \pm 0.8$ \\
\hline \multicolumn{8}{|c|}{ Mean } \\
\hline $0-22$ & $2.4 \pm 0.5$ & $0.733 \pm 0.04$ & $0.067 \pm 0.006$ & $0.058 \pm 0.004$ & $0.023 \pm 0.005$ & $0.881 \pm 0.04$ & $37 \pm 1.7$ \\
\hline $22-55$ & $2.8 \pm 0.6$ & $0.602 \pm 0.2$ & $0.064 \pm 0.008$ & $0.048 \pm 0.004$ & $0.033 \pm 0.009$ & $0.747 \pm 0.08$ & $27 \pm 1.2$ \\
\hline
\end{tabular}

Table 3. Chemical characteristics of poultry and cattle manures used. Data are means \pm standard error.

\begin{tabular}{lccccccc}
\hline Manure type & $\mathbf{C}(\%)$ & $\mathbf{N}(\%)$ & $\mathbf{P}(\%)$ & $\mathbf{K}(\%)$ & $\mathbf{C a}(\%)$ & $\mathbf{M g}(\%)$ & $\mathbf{C : N}$ \\
\hline cattle & $26.52 \pm 1.1 \mathrm{~b}$ & $0.92 \pm 0.01 \mathrm{~b}$ & $0.19 \pm 0.01 \mathrm{~b}$ & $0.79 \pm 0.01 \mathrm{~b}$ & $0.48 \pm 0.02 \mathrm{~b}$ & $0.31 \pm 0.03 \mathrm{a}$ & $28.83 \pm 0.1 \mathrm{~b}$ \\
poultry & $30.93 \pm 1.6 \mathrm{a}$ & $2.09 \pm 0.03 \mathrm{a}$ & $0.87 \pm 0.02 \mathrm{a}$ & $0.97 \pm 0.05 \mathrm{a}$ & $1.06 \pm 0.03 \mathrm{a}$ & $0.34 \pm 0.02 \mathrm{a}$ & $14.8 \pm 0.2 \mathrm{a}$ \\
\hline
\end{tabular}

Different letters within a column represent significant difference (t-test, $p<0.01)$.

was collected in 3 firms of the area. Poultry manures had a storage time in the heaps ranged from five to seven months. The manure samples were analyzed at the laboratory. All samples were dried in a forced-air oven at $60^{\circ} \mathrm{C}$ and ground to $0.5 \mathrm{~mm}$ for analysis. Total 
organic carbon was determined by oxidation with $\mathrm{K}_{2} \mathrm{Cr}_{2} \mathrm{O}_{7}$ in $\mathrm{H}_{2} \mathrm{SO}_{4}$, according to Yeomans and Bremner (1989). $\mathrm{NH}_{4}{ }^{+}-\mathrm{N}$ was extracted with $2 \mathrm{M} \mathrm{KCl}$ and determined calorimetrically by the phenol salt method (Honeycult et al., 1991). NO3-N was determined by secondderivative spectroscopy in a 1:30 (w/v) water extract (Sempere et al., 1993). Total nitrogen $\left(\mathrm{N}_{\mathrm{t}}\right)$ and organic nitrogen $\left(\mathrm{N}_{\text {org }}\right)$ were calculated as the sum of Kjeldahl-N and $\mathrm{NO}^{-}-\mathrm{N}$ and as the difference between $\mathrm{N}_{t}$ and the inorganic nitrogen (sum of $\mathrm{NH}_{4}{ }^{+}-\mathrm{N}$ and $\mathrm{NO}^{-}-$ $\mathrm{N})$, respectively. Manure samples were also analysed to determine with $0.1 \mathrm{M} \mathrm{HCl}+0.03 \mathrm{M} \mathrm{NH}_{4} \mathrm{~F}$ (Bray II method) extractable $\mathrm{P}$ and $\mathrm{K}$ (Salinas and Garcia, 1985), $1 \mathrm{M} \mathrm{KCl}$ extractable Ca, Mg (Thomas, 1982).

\section{Experimental design}

The trial was set up according to a randomized complete blocks design. Three (3) treatments with four (4) blocks containing 4 replications per treatment were set up in experimental plots of $64 \mathrm{~m}^{2}$ each, with $1 \mathrm{~m}$ distance between plots. The manure was spread at the dose of $10 \mathrm{t} / \mathrm{ha}$ after randomization. Then, the plots were ploughed and uniformly mixed with the manures before planting the cassava. Cassava cuttings were planted on 6 June, 2002. The second test was set up, one year after, then, at the same date in 2003. Each treatment was sampled ( 9 taking away) for 2 layers of soil $(0-22$ and $22-55 \mathrm{~cm}$ ). These taking away were made at the harvest time at 15 month after planting in September.

Depth of horizon was measured by digging small pits, then measuring the depth where soil colour changed using the Munsell soil colour charts (Munsell (1954) cited in Schlichting et al. (1995)).

\section{Extraction method and evaluation of earthworms' population}

The earthworms were identified on all the treatments in the soil of 6 pits per treatment at 15 months after planting. Each pit measured 1 $\mathrm{m}$ length on $1 \mathrm{~m}$ breadth and $70 \mathrm{~cm}$ depth. The earthworms were collected together with the soil in a bucket which was regularly emptied on a plastic bag to locate the earthworms finely and count them thereafter.

\section{Statistical methods}

The data were subjected to the analysis of variance according to the experimental design (linear model with interactions), by the analysis software SAS® (Statistical Analysis System Institute Inc., Cary, NC, USA). For the significant effects, the averages were compared using Student-Newman_Keuls method (Dagnelie, 2003).

\section{RESULTS}

\section{Manures effects on earthworms population in the soil}

The Figure 1 shows the average number of earthworms in the amended soils. The average numbers of earthworms $H$. africanus (Olgochaeta, Eudrilidae) which were 7,13 , and 16 per $\mathrm{m}^{2}$ at $0-55 \mathrm{~cm}$ soil layers, respectively in the control plots, cattle manure plots and poultry manure plots were significantly affected by the manure $(p<$

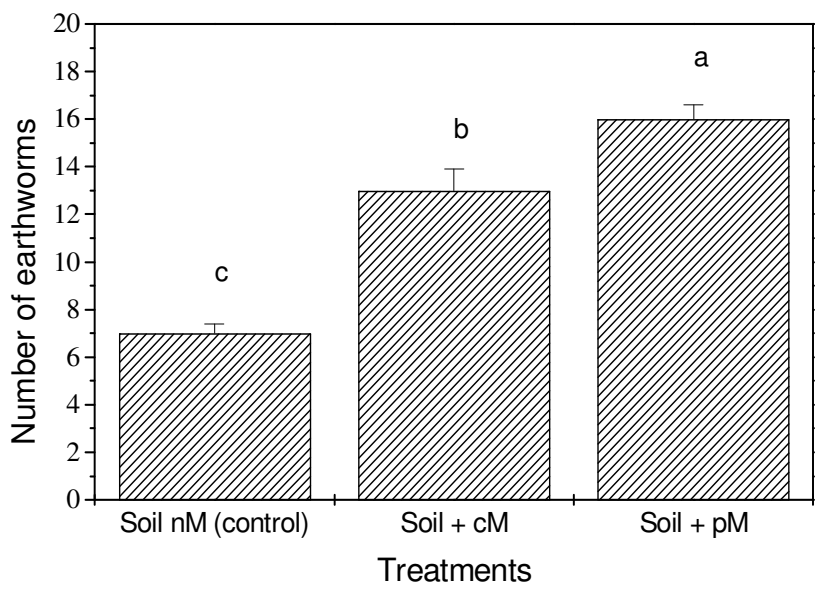

Figure 1. Average number of earthworms at $0-55 \mathrm{~cm}$ soil layers in one $\mathrm{m} 2$ of the sandy soil under cassava cultivation at 15 months after planting, according to fertilisation mode during the 2 consecutives crop years, without manure, cattle manure and poultry manure, Toumodi, Côte d'Ivoire. Errors bars are SE, histograms surmounted by different letter are significantly different at $\mathrm{p}<0.01$. nM: no Manure (control); $c M$ : cattle manure; pM: poultry manure.

0.01). This corresponded to an increase of $85 \%$ of earthworm population under cattle manures and $128 \%$ under manure poultry compared to the control.

\section{Manures effects on soil colour and particles size distribution}

The colour of the horizons was variable, ranging from boards $2.5 \mathrm{YR}$ to $10 \mathrm{YR}$. However, under the control, $100 \%$ of the samples were in the boards $10 \mathrm{YR}$ whereas under manure, there was only $25 \%$, with $62.5 \%$ in the board $7.5 \mathrm{YR}$ and $12.5 \%$ in the board $2.5 \mathrm{YR}$. The Table 4 shows the particle-size distribution in the treatments for 0 - 22 and $22-55 \mathrm{~cm}$ soil layers. The soils with manures had significantly higher clay and silt contents than those of the control $(p<0.01)$. However, the sand content was not significantly affected by either treatment. The particles size distribution of the soil indicated very sandy soils under the control, sandy under the cattle manure, sandy on the top horizon $(0-22 \mathrm{~cm})$ and sandy-clay on the sub horizon $(22-55 \mathrm{~cm})$ under the poultry manure. The clay contents were higher in the soil samples under manure.

\section{Manures effects on the soil chemical characteristics}

The amended soils had largest amount of organic matter, 
Table 4. Particle-size distribution in the treatments for $0-22$ and $22-55 \mathrm{~cm}$ soil layers, under cassava cultivation at 15 months after planting, according to fertilisation mode during the 2 consecutives crop years, without manure, cattle manure and poultry manure, Toumodi, Côte d'Ivoire. Data are means \pm standard error.

\begin{tabular}{cccccc}
\hline Treatments (cm) & Clay (\%) & Fine silt (\%) & Carse silt (\%) & Fine sand (\%) & Coarse sand (\%) \\
\hline \multicolumn{5}{c}{ Soil nM (control) } \\
\hline $0-22$ & $5.6 \pm 0.2 \mathrm{c}$ & $4.8 \pm 0.2 \mathrm{~d}$ & $8.3 \pm 0.4 \mathrm{~d}$ & $40 \pm 2.9 \mathrm{a}$ & $41.3 \pm 3.2 \mathrm{ab}$ \\
$22-55$ & $5.77 \pm 0.1 \mathrm{c}$ & $2.5 \pm 0.1 \mathrm{e}$ & $8.8 \pm 0.2 \mathrm{c}$ & $34.9 \pm 1.6 \mathrm{~b}$ & $46.2 \pm 2.6 \mathrm{a}$ \\
\hline \multicolumn{5}{c}{ Soil + cM } \\
\hline $0-22$ & $9.95 \pm 0.9 \mathrm{~b}$ & $6.3 \pm 0.3 \mathrm{~b}$ & $10 \pm 0.3 \mathrm{a}$ & $30.1 \pm 2.2 \mathrm{c}$ & $44.2 \pm 1.7 \mathrm{a}$ \\
$22-55$ & $6.95 \pm 0.3 \mathrm{~b}$ & $10.1 \pm 2.2 \mathrm{a}$ & $8.6 \pm 0.4 \mathrm{bc}$ & $35.9 \pm 1.9 \mathrm{ab}$ & $37.8 \pm 0.7 \mathrm{bc}$ \\
\hline \multicolumn{5}{c}{ Soil + pM } \\
\hline $0-22$ & $8.65 \pm 1.1 \mathrm{~b}$ & $6 \pm 0.7 \mathrm{~b}$ & $9 \pm 0.5 \mathrm{~b}$ & $32.4 \pm 2.7 \mathrm{~b}$ & $43.9 \pm 2.3 \mathrm{a}$ \\
$22-55$ & $16.5 \pm 2.6 \mathrm{a}$ & $5.5 \pm 0.2 \mathrm{c}$ & $7.4 \pm 0.6 \mathrm{~d}$ & $30.4 \pm 0.8 \mathrm{c}$ & $40.1 \pm 2.5 \mathrm{~b}$ \\
\hline
\end{tabular}

Values in the same column with different letter are significantly different at $p<0.05$. nM: No Manure (control); cM: cattle manure; $p M$ : poultry manure.

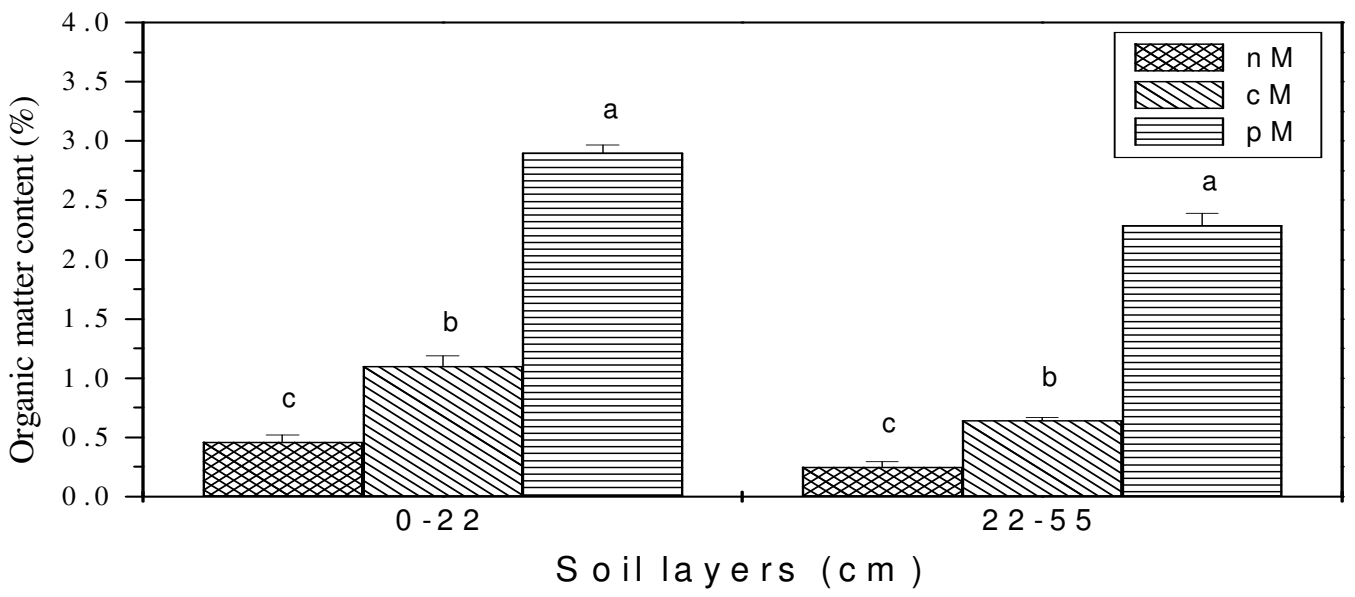

Figure 2. Responses in soil organic matter content at $0-22$ and $22-55 \mathrm{~cm}$ soil layers in the sandy soil under cassava cultivation at 15 months after planting, according to fertilisation mode during the 2 consecutives crop years, in the ferrallitic soil of the Toumodi area, Côte d'Ivoire. Errors bars are SE; histograms in the same soil depth, surmounted by different letter are significantly different at $p<0.01$. nM: no Manure (control); cM: cattle manure; pM: poultry manure.

sum of the exchangeable bases cations, cation exchange capacity and bases saturation. The difference between control values and manure values were significant $(p<$ 0.01 ).

The organic matter content (Figure 2) of the soil was very low in the control $(0.25-0.46 \%)$. It significantly increased in the soils treated with cattle manure $(1.1 \%$ in the top horizon) and with poultry manure $(2.9 \%$ in the top horizon).

The sum of the exchangeable bases cations (S) (Figure 3) was significantly higher under manure (2.9 - 10.2 me:
$100 \mathrm{~g})$ ) than under control $(0.8 \mathrm{me}: 100 \mathrm{~g})(\mathrm{p}<0.01)$. The CEC (Figure 4) was significantly lower under the control $(1.7-1.8 \mathrm{me}: 100 \mathrm{~g})$ than under the poultry manure $(8.5$ $12.8 \mathrm{me}: 100 \mathrm{~g})$ and the cattle manure $(3.8-11 \mathrm{me}: 100 \mathrm{~g})$ $(p<0.01)$.

The bases saturation content (V) (Figure 5) increased with the application of the manure. It significantly ranged from $47 \%$ with the control to $76 \%$ under cattle manure and $80 \%$ under poultry manure $(p<0.01)$. S, CEC and $V$ are the three values characterizing the soil adsorbent complex. 


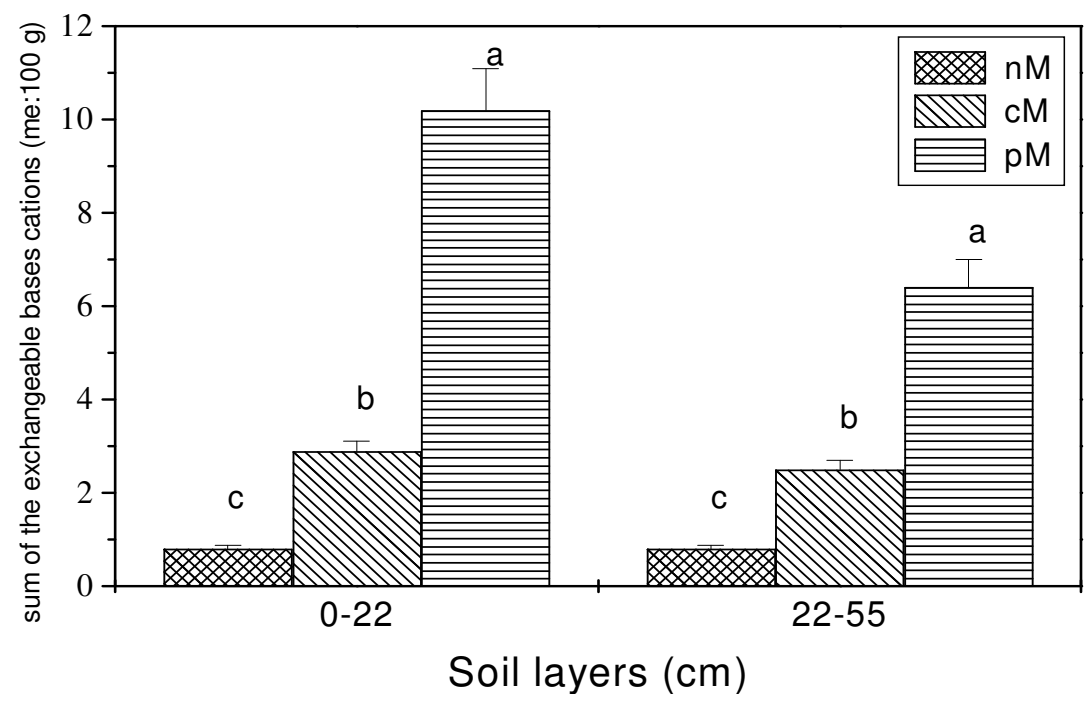

Figure 3. Responses in soil sum of the exchangeable bases cations at $0-22$ and $22-55 \mathrm{~cm}$ soil layers in the sandy soil under cassava cultivation at 15 months after planting, according to fertilisation mode during the 2 conse-cutives cropping years, in the ferrallitic soil of the Toumodi area, Côte d'Ivoire. Errors bars are SE; histograms in the same soil depth, surmounted by different letter are significantly different at $\mathrm{p}<0.01$. $\mathrm{nM}$ : no Manure (control); $\mathrm{cM}$ : cattle manure; pM: poultry manure.

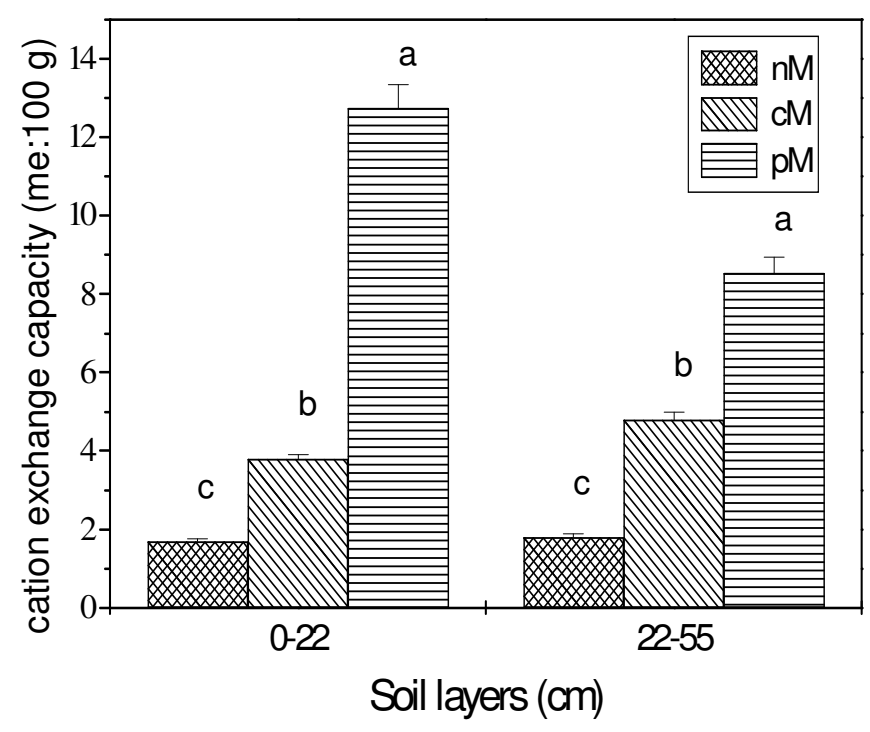

Figure 4. Responses in soil cation exchange capacity at 0 - 22 and $22-55 \mathrm{~cm}$ soil layers in the sandy soil under cassava cultivation at 15 months after planting, according to fertilization mode during the 2 consecutives crop years, in the ferrallitic soil of the Toumodi area, Côte d'Ivoire. Errors bars are SE; histograms in the same soil depth, surmounted by different letter are significantly different at $p<0.01$. nM: no Manure (control); cM: cattle manure; pM: poultry manure.

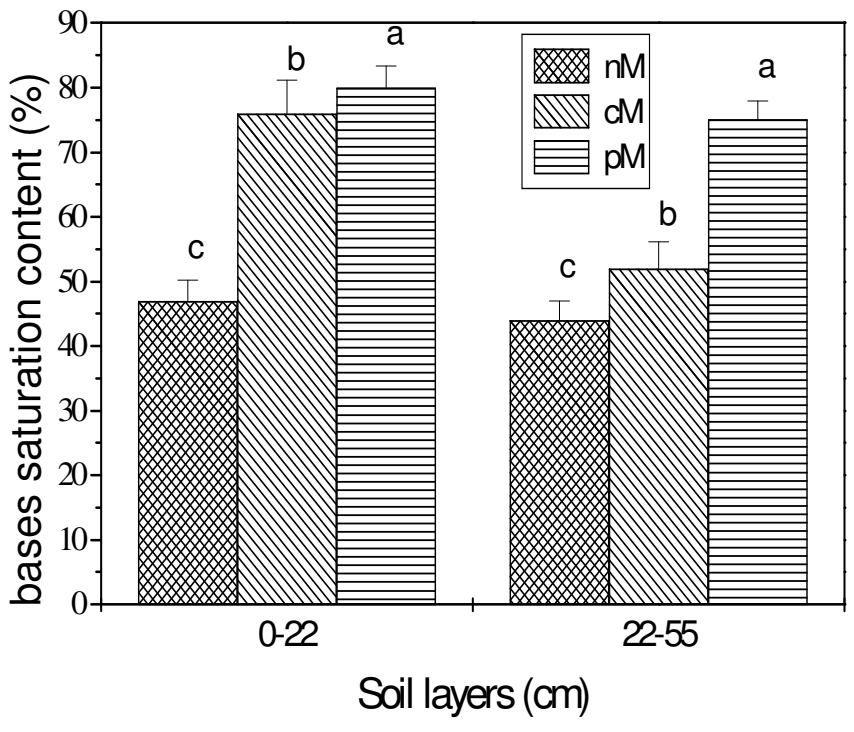

Figure 5. Responses in soil bases saturation content at 0 - 22 and $22-55 \mathrm{~cm}$ soil layers in the sandy soil under cassava cultivation at 15 months after planting, according to fertilisation mode during the 2 consecutives cropping years, in the ferrallitic soil of the Toumodi area, Côte d'Ivoire. Errors bars are SE; histograms in the same soil depth, surmounted by different letter are significantly different at $\mathrm{p}<0.01$. nM: no Manure (control); cM: cattle manure; pM: poultry manure. 


\section{DISCUSSION}

In this research, the aims were to study the organic fertilization effects on the status of a sandy soil and its relationships to other edaphic characteristics (physical, chemical and biological).

Concerning the manures analysis, the average carbon content ranged from 26.52 to $30.93 \%$, with, statistically, the poultry and cattle manures having highest and lowest carbon concentration, respectively. However, all the manures had carbon contents higher than the limit set by the Spanish legislation for organic fertiliser $(18 \% \mathrm{C})$ (BOE, 1998). The $\mathrm{N}$ concentration ranged from 0.92 to $2.09 \%$, with only the poultry manure showing a value of this parameter above the limit set for organic fertiliser $(2 \% \mathrm{~N})$ (BOE, 1998). The organic amendment quality and their capacity to provide nitrogen are generally evaluated by the C:N ratio (Stevenson, 1984). The poultry manure had significantly the lowest C:N ratio value (14.8) compared to cattle manure (the $\mathrm{C}: \mathrm{N}$ ratio value was 28.83 ). This low value was due to its $\mathrm{N}$ content being the highest. All the manures showed a $\mathrm{C}: \mathrm{N}$ ratio greater than the range of values for organic fertilisers (C:N = $3-15)$ (BOE, 1998). The carbon of these manures might have started its biodegradation process during the storage in heaps at the margins of the farms. In all manures, the $\mathrm{C}: \mathrm{N}$ ratio was over 12, which is the maximum value for mature composts prepared with a wide range of organic wastes (Bernal et al., 1998).

When litter with a high C:N ratio (approximately $30 / 1$ or higher) is added to soil, net immobilisation may occur for a period of time (days to weeks) which is dependent on the prevailing soil moisture and temperature. After a proportion of $C$ from the litter source has been consumed by organisms and respired (significantly reducing the overall $\mathrm{C} / \mathrm{N}$ ratio of the substrate) net mineralization may occur (Peter and Sinclair, 2001).

The manures influenced the soil infection by the earthworms. It is besides a good indicator of the soil fertility because the worms' casts have a strong assimilable nitrogen content, trace elements, organic matter, phosphorus and potassium (Flückiger et al., 1998). The worms dig galleries; also take part in the ventilation of the soil and its drainage, hence more water would be available for root growth. The higher number of earthworms with the poultry litter would be explained by the fact that the organic matter content is the highest.

The organic fertilization allowed significant increases in the soil organic matter contents in the $0-22 \mathrm{~cm}$ layer. That is due to the fact that the manure amendments on soil provide the nutritive elements by mineralization (Fan et al., 2004; Wuest et al., 2005). These results are similar to those of Wang et al. (2006) who observed that the cattle manure increased significantly the concentrations of the organic matter. The increase in the organic matter induced by the amendment is due to the manures which has three roles of organic matter sources, of protection of the soil against erosion and of increase in the activity of earthworms which reduce water runoff (Hole et al., 2005; Parfitt et al., 2005). In accordance with our results and with those of Hao and Chang (2002), the cattle manure involved an increase in the sum of the exchangeable bases cations $\left(\mathrm{Ca}^{2+}, \mathrm{Mg}^{2+}, \mathrm{K}^{+}, \mathrm{Na}^{+}\right)$and the cation exchange capacity $\left(\mathrm{Ca}^{2+}, \mathrm{Mg}^{2+}, \mathrm{K}^{+}, \mathrm{Na}^{+}, \mathrm{H}^{+}, \mathrm{Al}^{3+}\right)$. This tendency was accentuated with the poultry litter. Under the climatic conditions where the temperature and moisture are high, the mineralization processes of the organic matter of the soil are intense (Thuriès et al., 2000). This trend is observed because of the usual greater microbial activities associated due to organic matter accumulation.

The manures significantly increased in the same occasion the content of saturation in bases $(V=S: C E C)$. The amended soils were more fertile than the control, and this is reflected by the significant difference between the bases saturation contents obtained at both treatments. These results are in agreement with the conclusions of other researchers (Thuriès et al., 2000) who observed that the manure allowed significant increases in $\mathrm{C}, \mathrm{N}$ and CEC soil contents. Indeed, the fast mineralization of the organic matter provides the nutritive elements which constitute a surplus compared to the initial soil (Oehl et al., 2004). Similar results were obtained by Bado (2002), when he applied manure to soil of Farakô-Ba in Burkina-Faso.

\section{Conclusion}

In a system integrating farming and breeding, the use of the animal manure makes it possible to improve the soil properties, due to their very high organic matter contents. At the field, the manures improve the soil fertility. Such a system will allow a recycling of the nutritive elements ensuring a sustainable management of the soil fertility. Better than the practice of the fallow which is less and less possible with the strong pressure on the cultivable soils, the manures offer alternatives more interesting for a continuous and long-term exploitation of the fertility of the soils.

\section{ACKNOWLEDGMENTS}

This study was financed mainly by Nestle $R$ and $D$ Center and the Swiss Research Co-operation (SRC). Technical support was provided by the Swiss Centre for Scientific Research (CSRS, Côte d'Ivoire) and the University of 
Cocody (Côte d'Ivoire). We thank Dr Monsan Vincent (University of Cocody) for the statistical analysis and Dr Olivier GIRARDIN for valuable critical remarks.

\section{REFERENCES}

AFNOR (1996). Qualité des sols. Méthodes d'analyses, Recueil de normes françaises, France.

Arriaga FJ, Lowely B (2003). Soil physical properties and crop productivity of an eroded soil amended with cattle manure. Soil Sci. 168:888-899.

Asadu CLA, Nweke FI, Ekanayake IJ (1998). Factors affecting the fertility status of soils growing cassava in sub-saharan Africa. Commun. Soil Sci. Plant Anal. 29:141-159.

Bado BV (2002). Rôle des légumineuses sur la fertilité des sols ferrugineux tropicaux des zones guinéenne et soudanienne du Burkina Faso. Thèse de doctorat, Université Laval, Faculté des Sci. de l'Agric. et de l'Alimentation, Québec, Canada.

Bernal MP, Paredes C, Sanchez-Monedero MA, Cegarra J (1998). Maturity and stability parameters of compost prepared with a wide range of organic wastes. Biores. Technol. 63:91-99.

BOE (1998). Orden de 28 de mayo sobre fertilizantes y afines. Boletin Oficial del Estado p.131.

Carsky RJ (2003). Response of cowpea and soybean to P and K on terre de barre soils in southern Benin. Agr. Ecosyst. Environ. 100:241-249.

Cock JH, Howeler RH (1978). The ability of cassava to grow on poor soils. Crop Tolerance to Suboptimal Land Conditions. Am. Soc. Agron. Spec. Publ. 32:145-154

Dagnelie P (2003). Principes d'expérimentation, planification des expériences et analyse de leurs résultats. Les presses agronomiques, Gembloux.

Fan T, Stewart BA, Yong W, Junjie L, Guangye Z (2005). Long-term fertilization effects on grain yield, water-use efficiency and soil fertility in the dryland of Loess Plateau in China. Agr. Ecosyst. Environ. 106: 313-329.

Flückiger R, Rösch J, Sturny W, Vökt U (1998). Le sol, la fumure dirigée. Allemagne.

Hao X, Chang C (2002). Effect of 25 annual cattle manure applications on soluble and exchangeable cations in soil. Soil Sci. 167:126-134.

Hao X, Chang C, Li X (2004). Long-term and residual effects of cattle manure application on distribution of $\mathrm{P}$ in soil aggregates. Soil Sci. 169:715-728.

Harris $F$ (2002). Management of manure in farming systems in semiarid West Africa. Exp. Agric. 38:131-148

Hole DG, Perkins AJ, Wilson JD, Alexander IH, Grice PV, Evans AD (2005). Does organic farming benefit biodiversity? Biol. Conserv. 122:113-130.

Honeycult CW, Potar LJ, Halteman WA (1991). Predicting nitrate formation from soils, fertilizers, crop residue and sludge with thermal units. J. Environ. Qual. 20:850-856.

Houba VJG (1995). Soil analysis procedures, other procedures. In: Van Der Lee JJ, Novozamsky I (eds) Soil and Plant Analysis, part 5B, Syllabus, pp.100-125.

Institut National de la Statistique (1998). Premiers résultats définitifs du RGPH 98, Bureau Technique du Recensement. Abidjan, Côte d'Ivoire.

Moares DC, Sciama D, Dambrine E, Dupouey JL, Gégout JC, Brechet C (2001). Evolution des stocks de carbone et de la disponibilité de l'azote lors de la dynamique de recolonisation des prairies abandonnées du Jura. Etud. Ges. Sol. 8:119-134.

Moral R, Moreno-Caselles J, Perez-Murcia MD, Perez-Espinosa A, Rufete B, Paredes C (2005). Characterisation of the organic matter pool in maures. Biores. Technol. 96:153-158.
Nyamangara J, Gotosa J, Mpofu SE (2001). Cattle manure effects on structural stability and water retention capacity of a granitic sandy soil in Zimbabwe. Soil Till. Res. 62:157-162.

Oehl F, Frossard E, Fliessbach A, Dobois D, Oberson A (2004). Basal organic phosphorus mineralization in soils under different farming sys. Soil Biol. Biochem. 36:667-675.

Ofori CS (1973). Decline in fertility status of a tropical Ochrosol under continuous cropping. Exp. Agric. 9:15-22

Ouattara K, Ouattara B, Assa A, Sédogo PM (2006). Long-term effect of ploughing, and organic matter input on soil moisture characteristics of a Ferric Lixisol in Burkina Faso. Soil Till. Res. 88:217-224.

Parfitt RL, Yeates GW, Ross DJ, Mackay AD, Budding PJ (2005). Relationships between soil biota, nitrogen and phosphorus availability, and pasture growth under organic and conventional management. Appl. Soil Ecol. 28:1-13.

Peter RG, Sinclair KM (2001). Carbon dynamics and nutrients mineralisation. In: Kirschbaum MUF, Mueller R (eds) Net Ecosystem Exchange: workshop proceedings $\mathrm{CRC}$ for greenhouse accounting, Canberra, Australia, 18-20 April pp. 89-94.

Salinas JG, Garcia R (1985). métodos quimicos para el analisis de suelos acidos y plantas forrajeras. Centro Internacional de Agric. Tropical (CIAT), Cali, Colombia.

Schlichting E, Blume HP, Stahr K (1995). Bodenkundliches Praktikum: Eine Einführung in pedologisches Arbeiten für Ökologen, insbesondere Land und Forstwirte und für Geowissenschaftler. BlackwellWissenschafts Verlag, Berlin.

Sempere A, Olivier J, Ramos C (1993). Simple determination of nitrate in soils by second-derivative spectroscopy. J. Soil Sci. 44:633-639.

Stevenson JF (1984). Humus Chemistry, genesis, composition, reactions. John Wiley \& sSn, New York, USA.

Swarup A, Manna MC, Singh GB (2000). Impact of land use and management practices on organic dynamics in soils of India. In Lal et al. (eds) Global climatic change and tropical ecosystem, Advance in Soil Science CRC/Press, Boca Raton, New York, pp. 261-281.

Thomas GW (1982). Exchangeable cations. In Page AL (ed) Methods of Soil Analysis. Am. Society of Agronomy, Madison, WI, USA.

Thuriès $L$, Arrufat $A$, Dubois $M$, Feller $C$, Herrmann $P$, Larré-Larrouy MC, Martin C, Pansu M, Rémy JC, Viel M (2000). Influence d'une fertilisation organique et de la solarisation sur la productivité maraîchère et les propriétés d'un sol sableux sous abri. Etud. Ges. Sol. 7:73-88.

Van Reeuwijk LP (1993). Procedures for Soil Analyses. Technological paper No. 9, Int. Soil Reference and Info. Centre (ISRIC).

Walkley A, Black JA (1934). An examination of the Detjareff method for determining soil organic matter and a proposed modification of the chromatic acid titration method. Soil Sci. 37:29-38.

Wang P, Durkalski JT, Yu W, Hoitink HAJ, Dick WA (2006). Agronomic and soil responses to compost and manure amendments under different tillage sys. Soil Sci. 171:456-467.

Wuest SB, Caesar-Ton That TC, Wright SF, Williams JD (2005). Organic matter addition, $\mathrm{N}$, and residue burning effects on infiltration, biological, and physical properties of an intensively tilled silt-loam soil. Soil Till. Res. 84:154-167.

Yeboah E, Ofori P, Quansah GW, Dugan E, Sohi SP (2009). Improving soil productivity through biochar amendments to soils. Afr. J. Environ. Sci. Technol. 3:34-41

Yeomans JC, Bremner JM (1989). A rapid and precise method for routine determination of organic carbon in soil. Commun. Soil Sci. Plant Anal. 19:1467-1475. 